\title{
Economic Policy Uncertainty and Firms' Cash Dividend Policies
}

\author{
Qiu-Min Liu' ${ }^{1}$, Chi-Chuan Lee ${ }^{2}$ and Ruyu Zhang ${ }^{3 *}$ \\ ${ }^{1}$ School of Management, Beijing Normal University Zhuhai, Zhuhai 519000, China; \\ ${ }^{2}$ School of Management, Beijing Normal University Zhuhai, Zhuhai 519000, China; \\ ${ }^{3}$ School of Management, Beijing Normal University Zhuhai, Zhuhai 519000, China. \\ * Corresponding author
}

Keywords: Economic policy uncertainty; dividend distribution decision; economic development; financial decision

\begin{abstract}
This paper adopted China’s Economic Policy Uncertainty (EPU) compiled by Baker et al. (2016) to study the impact of uncertainty and other factors on the dividend decision of listed companies, from the macro and micro perspectives. Empirical analysis was performed by the fixed effects model. It was found that the rise of economic policy uncertainty and the economic depression will inhibit corporate dividend distribution, and that equity concentration is significantly positively correlated with the level of corporate dividend payout in China. This paper extended on the study of policy uncertainty on corporate dividend distribution behavior, and concluded that the government should formulate transparent and stable economic policies, reduce the negative impact of uncertainty on enterprises, so as to promote the development of real economy.
\end{abstract}

\section{Introduction}

The impact of uncertainty on economic activities and financial markets has long been cared by many scholars. The global financial crisis caused by the US sub-prime mortgage crisis in 2007 has further facilitated academics, industries and governments to pay more attention to the impact of uncertainty on the real economy. Regarding the influence of uncertainty, in addition to economic analysis at the national level, the literature primarily focuses on firm's decision-making. The impact brought by changes in economic and political policies and systems will directly affect dividend distribution decisions, making companies more prudent to make decisions. Therefore, whether it is on economic policies or enterprise behavior, the impact of economic policy uncertainty is highly valued.

The majority of the previous literature only selected a single policy indicator without the consideration of policy or institutional uncertainty. Regarding the factors affecting the dividend policy, most scholars only focused on the internal structure of the company, and rarely considered the impact of macroeconomic condition. This paper conducts an empirical research on economic policy uncertainty and dividend policies of companies with a comprehensive measurement that takes policy and institutional uncertainty into consideration, from economic and enterprise stances. The research can not only enrich the studies of corporate finance and macroeconomics, but also have important reference value for China's enterprises and economic development and related policy formulation.

\section{Literature Review}

In abroad, Jensen [1] proposed free cash flow hypothesis based on the agency, and believed that more cash dividends could be paid with equity concentration, reducing agency costs. Later, many scholars, such as Fama and French [2], have introduced factors such as profitability, company scale and shareholding structure in the study of factors affecting dividend policy. After the financial crisis, many scholars came to observe the impact of the macroeconomic uncertainty on enterprises. What's more, with the introduction of the economic policy uncertainty, there were also researches on its impact on corporate activities. Pastor and Veronesi [3] from the perspective of shareholders, found that the increase of economic policy uncertainty made it difficult for investors to judge the development of the company, thereby reducing direct investment in enterprises. 
Domestic research has used official moves to measure political uncertainty and examine its impact on corporate behavior. Lei et al. [4] argued that political uncertainty drives companies to reduce dividend payments significantly. Huang and Guo [5] held that the uncertainty has a significant impact on adjusting the relationship between the power of CEO and dividends policy, and will increase the possibility of listed companies stopping or reducing cash dividends. Rao et al. [6] found that China Economic Policy Uncertainty Index had a negative impact on corporate investment.

In general, most literature on the decision of dividend distribution, center on the equity structure and other basic factors that affect the distribution of dividends. Few make comprehensive considerations from the from the micro- and macro- perspective, especially study the influence mechanism of economic policy uncertainty on dividend distribution decision. It can be seen that the relationship between economic policy uncertainty and dividend distribution decision remains to be studied systematically.

\section{Empirical Analysis}

\subsection{Variables selection and their definition}

This paper chooses the after-tax value of cash dividends as the dependent variable, and takes the economic policy uncertainty constructed by Baker et al. [7] as the core explanatory variable, and categorizes the control variables into micro and macro control variables. The micro control variables also include the ownership structure. The definition of the variables is presented in Table 1.

\section{Table 1 Variables' definitions}

\begin{tabular}{ll}
\hline Variable & Definition \\
\hline $\begin{array}{l}\text { Dependent variables } \\
\text { After-tax cash dividend per share (DIV) }\end{array}$ & After-tax value of cash dividend / issued common shares \\
$\begin{array}{l}\text { Economic policy uncertainty (EPU) } \\
\text { Micro Control variables }\end{array}$ & Year-end index constructed by Baker et al.(2016) \\
$\begin{array}{l}\text { Cash flow (CF) } \\
\text { Investment opportunity (TQ) }\end{array}$ & Net cash flow generated by current economic activities/total assets \\
$\begin{array}{l}\text { Firm size(FS) } \\
\text { Return on assets (ROA) } \\
\text { Ownership structure }\end{array}$ & $\begin{array}{l}\text { Tobin Q, market value / total assets } \\
\text { Herfindahl Index (H1) }\end{array}$ \\
$\begin{array}{l}\text { Managerial ownership ratio (MAO) } \\
\text { Macro Control variables }\end{array}$ & $\begin{array}{l}\text { HHI based on percentage shares held by the largest shareholders } \\
\text { Gross domestic product growth rate(GDP) }\end{array}$ \\
$\begin{array}{l}\text { Inflation rate(INF) } \\
\text { Unemployment rate(UNE) }\end{array}$ & $\begin{array}{l}\text { The annual growth rate of gross domestic product } \\
\text { The annual growth rate of consumer price index }\end{array}$ \\
\hline
\end{tabular}

(1) The main variable is economic policy uncertainty (EPU) which was produced by Baker et al. [7] from Stanford University and University of Chicago to show the uncertainties of economy and policy of countries. The larger the index, the higher the uncertainties of economy and policy.

(2) Cash flow (CF) and Tobin Q value (TQ). The higher the CF, the more adequate the company's accumulated surplus, the greater the potential agency cost of the manager, and the stronger the ability to pay cash dividends. The TQ value is negatively correlated with the distribution level, as the growth of company means that requires sufficient operating cash flow.

(3) Micro control variables include firm size (FS) and return on assets (ROA). The larger the asset size, the easier it is for the company to raise funds. Therefore, the asset size is positively correlated with the company cash dividend distribution. In terms of profitability, the return on total assets is selected as the proxy variable. 
(4) Ownership structure contains the ratio of the sum of the squared percentage shares held by the largest shareholders (H1) and the managerial administrator ownership ratio (MAO). As the equity is highly concentrated in China, the dividend policy usually favors major shareholders [8]. Therefore, the larger the $\mathrm{H} 1$, the larger the possibility of cash dividend payment. Scholars like Dong and Li [9] believe that managerial ownership can increase dividends as they reduce agency cost of the free cash flow, and significantly improve the cash dividend payment of companies with high agency costs. Therefore, it is expected that the two variables of ownership structure are positively correlated with the level of cash dividends.

(5) Macro control variables (M) consist of gross domestic product growth rate, inflation rate, and urban registered unemployment rate. When the GDP growth rate increases and the economy runs well, companies may send positive signals to investors through cash distribution, and may also use excess cash flow for new investments. Therefore, GDP growth rate can be positively and negatively correlated with corporate dividend payout. The increase of inflation rate brings currency devaluation, and most companies will hesitate to distribute during this period. The higher the unemployment rate, the more depressed the macro economy. In this way, the company usually reduces the cash dividend payment level to increase the operating cash flow.

\subsection{Model design}

Four models are built in this paper with dividend per common share after tax as the explained variable, CF, TQ, FS, ROA of microcosmic enterprise as the main control variables and equity structure (X) and macro economy (M) as the major variables. EPU is also combined to further analyze affecting factors and their effect on cash dividend distribution decision in enterprises.

$$
\begin{aligned}
& D \mathrm{IV}_{\mathrm{it}}=\alpha_{\mathrm{i}}+\beta_{1} C F_{\mathrm{it}}+\beta_{2} T Q_{\mathrm{it}}+\beta_{3} F S_{\mathrm{it}}+\beta_{4} R O A_{\mathrm{it}}+\mu_{\mathrm{it}} \\
& D \mathrm{IV}_{\mathrm{it}}=\alpha_{\mathrm{i}}+\beta_{1} C F_{\mathrm{it}}+\beta_{2} T Q_{\mathrm{it}}+\beta_{3} F S_{\mathrm{it}}+\beta_{4} R O A_{\mathrm{it}}+\gamma X_{\mathrm{it}}+\mu_{\mathrm{it}} \\
& D \mathrm{IV}_{\mathrm{it}}=\alpha_{\mathrm{i}}+\beta_{1} C F_{\mathrm{it}}+\beta_{2} T Q_{\mathrm{it}}+\beta_{3} F S_{\mathrm{it}}+\beta_{4} R O A_{\mathrm{it}}+\gamma X_{\mathrm{it}}+\delta M_{\mathrm{it}}+\mu_{\mathrm{it}} \\
& D \mathrm{IV}_{\mathrm{it}}=\alpha_{\mathrm{i}}+\beta_{1} E P U_{\mathrm{it}}+\beta_{2} C F_{\mathrm{it}}+\beta_{3} T Q_{\mathrm{it}}+\beta_{4} F S_{\mathrm{it}}+\beta_{5} R O A_{\mathrm{it}}+\gamma X_{\mathrm{it}}+\delta M_{\mathrm{it}}+\mu_{\mathrm{it}}
\end{aligned}
$$

\subsection{Sample selection and data resource}

Annual data of A-share listed companies in Shanghai and Shenzhen stock market from 2003 to 2016, provided by GTA CSMAR Database, is selected to be the research sample, in which data of core explanatory variable (EPU) is from China Year-end Index of Economic Policy Uncertainty (www.PolicyUncertainty.com.), authorized by Baker et al. [7], while data of macro control variables is form National Bureau of Statistic (NBS) with their annual increase rate calculated later.

Considering the veracity and reliability of data, the research team conducts the following procedures: (1) defective listed financial companies (less than one year) with dividends distributed are removed from the sample; (2) extreme data is removed while Winsorize of $1 \%$ up and down is conducted on continuous variables. Ultimately, 3,002 enterprises with 25,779 unbalanced panels are taken into research and analysis.

\subsection{Regression analysis and results}

Regression analysis results of four models are presented in Table 2. In Model 1, CF is not significant while other variables work well. Meanwhile, there is a strong negative correlation between TQ and DIV, while FS and ROA are significantly and positively correlated with DIV, which means excess cash flow are prone to be used for company's expansion and development instead of paying cash dividends when facing investment opportunity. In contrast, companies with larger scale would prefer paying more cash dividends, which is basically in line with previous research. In addition, regression coefficient of ROA (1.7894) hits higher value than other variables, not only demonstrating strongly positive effect ROA lays on dividend per common share after tax, but also showing that profitability plays an important role in dividend decision with high relevancy between them.

All variables approve in Model 2 after two variables presenting equity structure are added, while H1 and MAO are significantly and positively correlated with DIV. The result illustrates that high equity concentration has significantly positive effect on decision of dividend distribution, increasing the willingness of paying cash. High executive shareholding rate relates to low separation between shareholders and enterprise controlling, and agency problem of free cash flow would be mitigated while dividend distribution enhanced. The result is in accordance with Yan [10] and other domestic research while difference exists 
when compared with major references abroad. Main points abroad, like Jensen [1] and his agency cost theory of cash dividend, introducing a substitution mechanism of management shareholding and cash dividend with negative correlation between them.

Table 2 Estimated results for different model specifications

\begin{tabular}{|c|c|c|c|c|c|c|c|c|}
\hline \multirow{2}{*}{$\begin{array}{l}\text { Explanatory Variables } \\
\mathrm{C}\end{array}$} & \multicolumn{2}{|c|}{ Model 1} & \multicolumn{2}{|c|}{ Model 2} & \multicolumn{2}{|c|}{ Model 3} & \multicolumn{2}{|c|}{ Model 4} \\
\hline & -0.3740 & $* * *$ & -0.5373 & $* * *$ & -0.3450 & $* * *$ & -0.3481 & $* * *$ \\
\hline CF & 0.0262 & & 0.0366 & $* *$ & 0.0421 & $* *$ & 0.0436 & $* *$ \\
\hline TQ & -0.0097 & $* * *$ & -0.0090 & $* * *$ & -0.0098 & $* * *$ & -0.0100 & $* * *$ \\
\hline FS & 0.0194 & $* * *$ & 0.0251 & $* * *$ & 0.0235 & $* * *$ & 0.0249 & $* * *$ \\
\hline ROA & 1.7894 & $* * *$ & 1.7435 & $* * *$ & 1.7428 & $* * *$ & 1.7425 & *** \\
\hline H1 & & & 0.1539 & $* * *$ & 0.1606 & $* * *$ & 0.1573 & *** \\
\hline MAO & & & 0.2040 & $* * *$ & 0.2042 & $* * *$ & 0.2013 & $* * *$ \\
\hline GDP & & & & & 0.0001 & & 0.0002 & \\
\hline INF & & & & & 0.0014 & $* *$ & 0.0014 & $* *$ \\
\hline UNE & & & & & -0.0385 & $* *$ & -0.0443 & $* * *$ \\
\hline EPU & & & & & & & $-1.47 \mathrm{E}-05$ & $* *$ \\
\hline $\mathrm{R}^{2}$ & 0.620 & & 0.624 & & 0.62 & & 0.6249 & \\
\hline Hausman & 0.000 & & 0.000 & & 0.00 & & 0.0000 & \\
\hline
\end{tabular}

Note: $* * *$ and $* *$ indicate statistical significance at the $1 \%$ and $5 \%$ levels, respectively.

It is possibly related to the lower level of cash dividend distribution and management shareholding in China's companies as well as smaller advantages that manager owning equity brings in alleviating the agency problem.

In Model 3, GDP fails the test of significance while other variables approve. INF has remarkable positive influence to dividend distribution, which means more price rising leads to lower real value of currency when cash dividend is preferred. UNE has a significant negative correlation with DIV, presenting a bearish macroeconomic trend and high level of layoff and unemployment, so that profit is tend be retained to guarantee adequate cash flow. Most previous literature focus on effect of financial crisis, such as Zhu and Wang [11] research suggests that cash dividend paying rate is reduced to avoid further loss caused by uncertain factors like decreasing profit in the future, which is consistent with the result of regression analysis in this thesis.

Finally, EPU and explained variable DIV present a negative correlation under 5\% (sig), demonstrating that economic uncertainty has significant negative effect on cash dividend paying. That is to say, when facing uncertain economic policy, the companies tend to reduce cash dividend paying. Specifically, enterprises can conduct flexible policies to reduce or stop cash dividend paying in front of uncertainty to enable enough cash holing. Currently, most literature research on relationship between political policies and dividend distribution decision instead of considering economic policy uncertainty's impact. However, results such as policy uncertainty laying negative effect on cash dividend paying present agreement with this thesis to some extent.

It is also noticeable that with variables of various aspects added, regression coefficient of CF and FS's positive effect on DIV is getting larger while that of TQ sees little variation and ROA modestly decreases. After considering equity structure, macro economy and EPU, main variables in the thesis would produce certain effect to dividend distribution decision more or less. For instance, with higher equity concentration and executive shareholding, cash flow and company scale would have increasing effect on the decision of paying cash dividend or not. It is primarily verified that companies with high equity concentration and low agency cost would consider cash dividend distribution on the basis of their cash flow and size. The result provides support for free cash flow theory and has been validated on account of previous literature. 


\section{Conclusion and Suggestion}

From the enterprise perspective and the macro economy, this paper adopts China Economic Policy Uncertainty (CEPU) compiled by Baker et al (2016) to study the impact of China's economic policy uncertainty and other factors on the dividend distribution decision of listed companies, from the macro and micro perspectives. It is concluded that when economic policy uncertainty rises, companies are less willing to distribute dividends. The empirical results have also confirmed some conclusions about the theory of dividend distribution and the past literature. For example, in terms of equity structure, equity concentration and executive shareholding ratio have positive influence on the level of Chinese companies' distribution. Moreover, with regards to macro economy, the worse the state of economy, the lower the intention of enterprises to distribute cash dividends.

The enlightenment of the study is that firstly, a transparent and stable policy mechanism in macro economy is very important for the management and decision-making of micro-enterprises. Enterprises can obtain reliable information and formulate a sound dividend-paying policy and reduce the losses caused by potential economic policy uncertainty. Secondly, in order to alleviate the agency problem of enterprises, it is necessary to improve the management supervision system and instruct enterprises to formulate reasonable and transparent dividend policies, as shares are relatively centralized and managers own lower level of share proportion.

\section{Acknowledgment}

This research was financially supported by the Guangdong Undergraduate Science and Technology Innovation Cultivation Special Fund (“Climbing Project”) (Grant Number: pdjhb0598).

\section{References}

[1]. M.C. Jensen, Agency costs of free cash flow, corporate finance and takeovers, American Economic Review, (76), pp.323-329, 1986.

[2]. E.F. Fama, and K.R. French, Disappearing dividends changing firm characteristics or lower propensity to pay,” Journal of Financial Economics, (11), pp.517-533, 2001.

[3]. L. Pastor, and P. Veronesi, Political Uncertainty and Risk Premia, Journal of Financial Economics, (110), pp.520-545, 2013.

[4]. G. Lei, W. Wang, and M. Liu, Political Uncertainty, Dividend Policy Adjustment and Market Effect, Accounting Research, (4), pp.33-39, 2015.

[5]. G. Huang, and D. Guo, Environmental uncertainty, CEO power and cash dividend distribution, Commercial Research, (8), pp.156-162, 2015.

[6]. P. Rao, H, Yue, and G. Jiang, Economic Policy Uncertainty and Firms' Investment, Journal of World Economy, (2), pp.27-49, 2017.

[7]. S.R. Baker, N. Bloom, and S.J. Davis, Measuring Economic Policy Uncertainty, Quarterly Journal of Economics, (131), pp. 1593-1636, 2016.

[8]. J. Xu, and Y. Zhang, On the Influence of Ownership Structure on the Dividend Policy of Listed Companies, Macroeconomics, (4), pp.54-55, 2013.

[9]. Y. Dong, F. Li, Managerial Ownership, Dividend Policy and Agency, China Economic Quarterly, (3), pp.16-35, 2011.

[10]. D. Yan, On the Influence of the Value Orientation of Shareholders of Chinese Listed Companies on Dividend Policy, Nankai Economic Studies, (6), pp.94-105,2004.

[11]. J. Zhu, C. Wan, The Effect of Financial Crisis on Cash Dividend Policies: From the Perspective of Ownership Structure, Accounting Research, (2), pp.38-44, 2013. 